\title{
RESENHA
}

\section{Mídia-Multidão: estéticas da comunicação e biopolíticas}

Diego COTTA ${ }^{1}$

O livro-conceito "Mídia-Multidão: estéticas da comunicação e biopolíticas", da pesquisadora e professora da Escola de Comunicação da Universidade Federal do Rio de Janeiro, Ivana Bentes emerge e logo se destaca em meio às novas publicações relacionadas às Ciências da Comunicação da contemporaneidade. Lançado no início de dezembro de 2015, durante o Emergências, na Fundição Progresso (Centro do Rio), um evento de resistência cultural e apoio à presidenta (afastada) da República Dilma Rousseff, o livro, publicado pela Editora Mauad, é fruto do projeto de pesquisa "Estéticas da Comunicação, Novos Modelos Teóricos no Capitalismo Cognitivo", desenvolvido por Bentes, com apoio do CNPq, na ECO-UFRJ.

A publicação é dividida em duas partes pela autora, a saber: "Mídia-multidão" e "Vidas-linguagens e os novos sujeitos do discurso". A primeira, que dá nome ao livro, reúne ensaios que problematizam e questionam um novo fazer jornalístico, que de nada tem a ver com os famigerados conglomerados comunicacionais. A propagação de fatos indubitavelmente de interesse social, que muitas das vezes são escamoteados ou, quando difundidos, são distorcidos pela velha mídia, neste contexto, ou melhor, a partir do novo conceito que Bentes desenvolve, é realizada nas e pelas ruas, onde o precariado e as adversidades do meio são partes constituintes desta estética comunicacional.

No decorrer da primeira parte do livro, a autora discorre sobre uma comunicação que, a seu ver, deve ser entendida como pós-mídia de massa, por carregar na sua essência um novo modus operandi, um devir comunicacional coletivo, horizontal e oriundo do grito e da sobrevivência. Ivana escreve sobre memética, multidão e, sobretudo, midialivrismo, problematizando, a partir de análises das coberturas via streaming da Mídia NINJA e também de vídeos-documentários, a forma engessada e clássica de se fazer cobertura de fatos, principalmente quando se estão em jogo o

${ }^{1}$ Mestre do Programa de Pós-graduação em Mídia e Cotidiano da Universidade Federal Fluminense (UFF).diegocotta@gmail.com 
questionamento e a desestabilização do Estado, que na maioria das vezes atua de forma beligerante com aqueles que o protestam.

Essa produção instantânea realizada por uma multidão heterogênea desloca os intermediários clássicos: a corporação jornalística, o jornalista profissional, as agências de notícias, põem em xeque a "reserva de mercado" que existia para os formadores de opinião corporativos e apontam para outros modelos e campos expandidos, em que não se pode pensar o homem desconectado de suas próteses e dispositivos (como enfatiza Bruno Latour [2012] na sua teoria Ator-Rede) (BENTES, 2015, p. 11).

É interessante observar a citação da teoria Ator-Rede de Bruno Latour (2012) logo no início do livro, pois a conexão com o cinema novo se faz quase que imediatamente. Bastante conhecida por conta de suas pesquisas sobre a obra de Glauber Rocha, Ivana Bentes revisita a máxima do seu objeto - "Uma câmera na mão e uma ideia na cabeça" - ao desconsiderar o homem que porventura esteja desligado de seus dispositivos. Inclusive, mais adiante, a pesquisadora jogará luz sobre tais próteses, valorizado-as não apenas como tecnologias capazes de capturar o real e difundi-lo instantaneamente, mas também como verdadeiras "armas" contra o Estado bélico.

As câmeras (smartphones, celulares) têm também uma função de vigilância. Durante as transmissões, vimos surgir e tomar consciência uma outra função da imagem, a imagem utilizada não apenas para "informar" ou relatar, através de uma câmera de combate e intrusiva (que responde aos movimentos mais sutis e ágeis, flexíveis, da palma da mão). Essa câmera intrusiva, às vezes imperceptível, serve como ferramenta/arma para "ferir" o inimigo, para vigiálo - tanto as imagens dos midiativistas quanto as imagens de registro, documentação, "fichamento" visual, feitas pelas câmeras da polícia (BENTES, 2015, p. 23).

Entretanto, esse combate que se dá nas ruas, não somente de maneira física e violenta, mas também de forma discursiva, isto é, o fervilhar de uma ruidocracia gerida em meio à polifonia nata de uma multidão multipertencida, de um público composto por indivíduos que podem pertencer a diferentes públicos, mas que estão ali produzindo conteúdo coletivamente e propagando-o como práxis transformadora é naturalmente por demais disruptivo. Esta característica (revolucionária) de desestabilização da maneira clássica de produção de conteúdo evidencia a essencialidade, a relevância e o êxito do midiativismo, a partir do momento que desconstrói e reformula o tácito.

Este circuito rede-rua que se vigora em transmissões midialivristas acontece a partir da valorização do afeto em detrimento dos discursos mercadológicos de inteligência emocional e/ou do mito de objetividade-imparcialidade jornalística. Muniz 
Sodré (2006, p.32) sugere que há um esforço daqueles que controlam a razão, a moral, de sobrepô-las às emoções e ao afeto porque “(...) o mundo moderno começa a suspeitar mais fortemente dos afetos ou paixões, enquanto instâncias de confusão ou de uma desmedida socialmente indesejável”. São essas afetividades que provocam as fissuras e estimulam as buscas por brechas de transformação.

Termos como afeição ou afecção, provenientes de affectus e afectio, segundo Sodré (2006, p.28-29), referem-se a um conjunto de estados que atua na função psíquica chamada de afetividade; já afeto, com a mesma etimologia, se refere a uma ação em particular sobre a sensibilidade de determinado ator. Nesse sentido, a ação de afetar, no latim clássico, contém o significado de emoção, pois corresponde a commuovere, comportando, um fenômeno afetivo que se define por um estado de choque ou de perturbação na consciência. Certamente, como Ivana Bentes explicita em seu livro Mídia-Multidão, não haveria fenômeno comunicacional, exemplificado pelas coberturas do MÍDIA NINJA ou pela produção de documentários como Rio em Chamas $^{2}$ e Depois rola o mocotón, se não houvesse afeto. Nas palavras da pesquisadora, "estamos diante de uma mobilização global político-afetiva nas ruas e nas redes. Os ciclos de lutas globais tornaram-se referência e laboratório global das novas lutas, e nessas experiências as imagens em tempo real produzem outra qualidade de relação com o presente e a constituição dos novos sujeitos políticos" (BENTES, 2015, p.19-20).

São vidas-linguagens. Produções audiovisuais colaborativas e insurretas, configurando uma estética comunicacional intrinsecamente ligada à biopolítica. A multidão põe em prática um fluxo cognitivo que se transforma na própria mídia e na própria luta. As imagens produzidas atravessam o mundo, ganham adeptos, apoiadores e multiplicadores ideológicos.

\begin{abstract}
Viralizados e ressignificados pelas redes, esse cinema de rua - cinemamundo, cinema-fluxo, de deriva, mídia-multidão, cinema insurgente - se espalha. As emissões ao vivo (streamming ou posteriormente editadas) são produzidas em regime de urgência e precariedade. Dramaturgia singular que atravessa, mas excede a própria história do documentário ou dos registros e emissões ao vivo da TV (BENTES, 2015, p. 22).
\end{abstract}

\footnotetext{
${ }^{2}$ Rio em Chamas. Direção: Daniel Caetano, Vinícius Reis, Clara Linhart, André Sampaio, Cavi Borges, Eduardo Souza Lima, Diego Felipe Souza, Luiz Cláudio Lima, Ana Costa Ribeiro, Ricardo Rodrigues, Vítor Gracciano, Luiz Giban. 2014.

3 Depois rola o mocotó. Direção e roteiro: Debora Herszenhut e Jeferson Oliveira (Don). Produção: Clandestino Filmes e Leonardo Edde, 2009.
} 


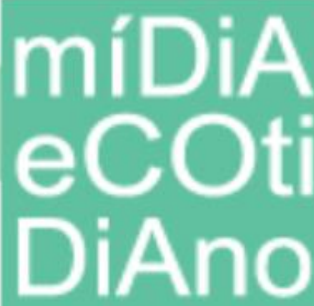

Depois de Junho de 2013 e das inúmeras manifestações que se sucederam no Brasil - pelas mais variadas motivações, "Mídia-Multidão" se torna uma leitura imprescindível para a compreensão dos atos de rua, sob a perspectiva de um novo devir comunicacional, especialmente pautado pela manipulação de dispositivos móveis conectados à rede. Como escreve Ivana, "tomadas na sua urgência e função (informar, mobilizar, comover, disputar sentidos), essas imagens atravessam diferentes fronteiras e tiram sua força do dorso do presente, mas trazem no seu interior potências e estéticas virtuais, nessas dramaturgias do grito" (2015, p. 22).

\section{Bibliografia}

BENTES, Ivana. Mídia-Multidão: estéticas da comunicação e biopolíticas. Rio de Janeiro: Mauad X, 2015.

LATOUR, Bruno. Reagregando o social: uma introdução à teoria do ator-rede. Trad. Gilson César Cardoso de Sousa. Salvador/Bauru: EDUFBA/EDUSC, 2012.

SODRÉ, Muniz. As Estratégias Sensíveis: Afeto, Mídia e Política. Petrópolis: Vozes, 2006. 